\title{
Influence of relative mobilities on the composition of benthic communities
}

\author{
Martin H. Posey* \\ Biology Department, University of Oregon, Eugene, Oregon 97403, USA
}

\begin{abstract}
A number of functional-group hypotheses have been proposed to explain the occurrence of distinct faunal assemblages in benthic communities. However, the generality of such interactions is uncertain. The predictions of a mobility-mode functional-group hypothesis are here compared with experimental studies in order to determine its usefulness as a model for community interactions. This hypothesis appears to provide a good predictive framework under limited conditions. Dense aggregations of large organisms or those with strong sedimentary effects may exclude smaller species through modifications related to their mobility type. However, the interactions are asymmetrical. Dense assemblages of smaller species have not been shown to exclude larger forms. These results suggest a reevaluation of the conditions necessary for mobility-related interactions to become important in regulating the composition of a benthic community. Although the mobility-mode theory describes the influence of active or large members of a tideflat community, care should be taken in assuming such interactions among smaller fauna.
\end{abstract}

\section{INTRODUCTION}

Species richness and abundance patterns in softsubstrate habitats are regulated by a variety of processes. Physical characteristics of the environment (e.g. sediment grain size and sorting), food availability, predation, aggressive interactions among species, and larval recruitment all may affect the composition of benthic communities. In addition to these factors, several researchers also have suggested that indirect interactions between groups of functionally similar organisms may play an important role in determining distribution patterns under certain conditions. These functional-group theories have suggested that dense aggregations of species with similar patterns of resource utilization may alter the environment so as to make it unfavorable to ecologically different forms (Woodin \& Jackson 1979, Thayer 1983). The proposed result of such indirect interactions is the formation of distinct, dense multispecies assemblages - potentially

- Present address: Smithsonian Environmental Research Center, PO Box 28, Edgewater, Maryland 21037, USA on a much smaller scale than might be expected from factors such as habitat difference or food availability.

A variety of functional-group theories have been proposed, differing primarily in the defining characteristics of the various groups and their modes of interaction. Trophic group amensalism (Rhoads \& Young 1970) suggests that organisms with different feeding types may exclude one another. Deposit feeders may exclude suspension feeders from subtidal muds by resuspending particles that clog their filtering apparatus. Wildish (1986) offered a revision of this hypothesis, suggesting that trophic group amensalism may be modified by impoverishment from such factors as tidal or wave erosion. Adult-larval interactions, where dense species assemblages are maintained through inhibition of recruitment by other groups, have been proposed to explain the occurrence of distinct patches of suspension-feeding clams, tube builders, and burrowing deposit feeders (Woodin 1976). Interactions between organisms of different mobility types have been suggested to produce discrete distributions of mobile and sedentary species (Brenchley 1981, 1982). Other functional group hypotheses have been 
based on feeding position (e.g. subsurface vs interface deposit feeders; Josefson 1985) or combinations and redefinitions of the above groups (Thayer 1983).

As suggested by the variety of theories, research on the role of functional-group interactions in soft-substrate communities has been extensive. However, the fit of observed patterns to those predicted by these theories has not always been good, leading to uncertainty about the usefulness of looking at functionallevel interactions. In the following discussion, the data is reviewed for one functional-group hypothesis, based on mobility modes, to assess its usefulness as a model for benthic community interactions. This hypothesis has been proposed to explain distributions in several communities and it readily lends itself to review because of the variety of studies involving species of different mobilities and the possibility of identifying mobility types with field observations. Available information suggests a modification of the theory as originally proposed, with mobility-group interactions assuming importance under a more restricted set of conditions than previously thought.

\section{MOBILITY INTERACTIONS}

The mobility-mode hypothesis was proposed to explain the occurrence of distinct, dense intertidal assemblages of sedentary and mobile species (Brenchley $1978,1981,1982)$. As originally suggested, burrowing activity (e.g. feeding, burrow construction, or foraging) associated with dense aggregations of mobile animals would disrupt the substrate and increase deposition of particles on the sediment surface. Increased disturbance and biodeposition will exclude or reduce densities of sedentary species through burial or by preventing the establishment of permanent tubes, burrows, or rhizome networks. Conversely, the tubes and rhizomes associated with many sedentary species would inhibit the burrowing of mobile animals by binding the sediment. These interactions are primarily controlled by the densities of the interacting species and are independent of relative sizes. They are also symmetrical. If present in sufficient densities, either group can exclude the other, making the dominance of one group over another strongly dependent on historical events. Groups of sedentary and mobile species are thus predicted to form non-overlapping patches, potentially located in close proximity since their existence is primarily density-dependent. It should be noted that other functional group theories may predict similar distributions under certain circumstances. For example, adult-larval interactions may produce distinct groups of tube builders and active burrowers. However, in this case the mechanism by which burrowers are proposed to exclude the juveniles of tube builders involves sediment disruption (Woodin 1976), similarly to the mobility-mode hypothesis.

\section{REVIEW OF DATA}

What is the evidence that mobility-related interactions lead to the formation of distinct assemblages in soft substrates? There are numerous examples of negative correlations between the distributions of mobile and sedentary organisms (Table 1; see Thayer 1983). Although many of these studies simply document disjunct distributions or note negative effects without elucidating causes, others have experimentally demonstrated the importance of mobility effects in producing observed patterns. In several experiments, the addition of a mobile burrower leads to reductions in the abundances of sedentary organisms. A large burrowing worm, Abarenicola pacifica, reduced numbers of small sedentary spionids when added to laboratory aquaria (Brenchley 1981, Wilson 1981). A. pacifica is a burrowing deposit feeder and its effects were primarily the result of disruption and transport of sediment associated with feeding. Densities of a tube-dwelling tanaid declined when they were exposed to disturbance by the burrowing sand dollar Dendraster excentricus in both laboratory and field addition experiments (Brenchley 1981, Highsmith 1982). Tubes of phoronids were broken or disorientated when these worms were transplanted into dense beds of a burrowing shrimp, Callianassa californiensis (Ronan 1975). Seagrass plants transplanted into a tropical Callianassa sp. bed showed declines in blade and shoot number, apparently due to increased sediment dumping in the area of a shrimp mound (Suchanek 1983). Similar increases in the mortality of small sedentary animals are observed when these organisms are exposed to $C$. californiensis in laboratory aquaria (Brenchley 1981, Murphy 1985) and removal of this shrimp in the field resulted in higher survivorship and recruitment of a more sedentary bivalve (Peterson 1977). C. californiensis is a nonpredatory deposit feeder (Posey 1985) and its effects on tube builders were similar to those observed with artificial sediment addition and disturbance (Brenchley 1981). A tube-dwelling amphipod, Microdeutopus gryllotalpa, showed increased emigration and decreased recruitment in the presence of a larger deposit-feeding snail, Myanassa obsoleta (DeWitt \& Levinton 1985). Examination of microflora indicated that this negative interaction was most likely due to disturbance by the snail and not food depletion. Sedentary organisms have also been shown experimentally to inhibit burrowing forms, with eelgrass and tube mats inhibiting penetration by Abarenicola 
Table 1. Mobility-mode interactions in soft-substrate habitats. Relative mobilities: $M_{1}$ mobile species; $S$, sedentary species Relative sizes: $l_{1}$ large $; i$, intermediate; $s$, small

\begin{tabular}{|c|c|}
\hline Source & Interaction \\
\hline Bird 1982 & $\begin{array}{l}\text { Thalassinid shrimp Callianassa californiensis (M-1) excluding tube-building polychaetes and } \\
\text { amphipods (S-s) }\end{array}$ \\
\hline Dorsey \& Synnot 1980 & Thalassinid Callianassa ceramica (M-l) excluding spionid polychaetes (S-s) \\
\hline Peterson 1977 & Thalassinid Callianassa californiensis (M-1) excluding bivalve Sanquinolaria nuttallii (S-l) \\
\hline Peterson 1979 & Thalassinid Callianassa californiensis (M-l) excluding bivalve Protothaca staminea (S-1) \\
\hline Posey 1986a & Thalassinid Callianassa californiensis (M-l) excluding spionid polychaetes (S-s) \\
\hline Ronan 1975 & Thalassinid Callianassa californiensis (M-l) excluding a phoronid (S-i) \\
\hline Stevens 1928 & Thalassinid Callianassa californiensis (M-l) inhibiting oysters (S-1) \\
\hline Suchanek 1983 & Thalassinid Callianassa sp. (M-l) excluding seagrass Thalassia testudinum (S-l) \\
\hline Brenchley 1981 & $\begin{array}{l}\text { Mixed assemblage of polychaete Abarenicola pacifica (M-i) and mud shrimp Upogebia pugettensis } \\
(\mathrm{M}-\mathrm{l}) \text { excluding spionid polychaetes (S-s) }\end{array}$ \\
\hline Brenchley 1981 & Sand dollar Dendraster excentricus (M-l) excluding spionid polychaetes (S-s) \\
\hline $\begin{array}{l}\text { DeWitt \& Levinton } \\
1985\end{array}$ & Mud snail Ilyanassa obsoleta (M-i) increasing emigration of a tube dwelling amphipod (S-s) \\
\hline Grant 1965 & Mud snail Ilyanassa obsoleta (M-i) inhibiting spionid polychaetes (S-s) \\
\hline Highsmith 1982 & Sand dollar Dendraster excentricus (M-1) excluding Leptochelia dubia (S-s) \\
\hline Wiltse 1980 & Predatory snail (Polinices duplicatus) (M-l) excluding spionid polychaetes (S-s) \\
\hline Josefson 1985 & Burrowing predators (M) and tube builders (S) negatively correlated \\
\hline Brenchley 1982 & $\begin{array}{l}\text { Root-tube matrix from eelgrass, Zostera marina, bed (S-1) inhibiting Abarenicola pacifica (M-i), } \\
\text { Upogebia pugettensis (M-1), Leptosynapta clarkii (M-i), Macoma nasuta (M-i) }\end{array}$ \\
\hline Ronan 1975 & Phoronid ( $\mathrm{S}-\mathrm{i}$ ) excluding bivalve Macoma (M-i) \\
\hline Warme 1967 & Marsh roots (S-1) inhibiting Callianassa californiensis (M-1) and burrowing polychaetes (M-i) \\
\hline Woodin 1981 & $\begin{array}{l}\text { Polychaete Diapatra cuprea (S-l) excluding horseshoe crab Limulus polyphemus (M-l) and blue crab } \\
\text { Callinectes sapidus (M-l) }\end{array}$ \\
\hline $\begin{array}{l}\text { Weinberg \& Whitlatch } \\
1983\end{array}$ & Clymenella torquata (S-s) enhancing growth of Gemma gemma (M-s) \\
\hline Wilson 1981 & Abarenicola pacifica (M-i) excludes Pygospio elegans (S-s) but not Psuedopolydora kempi (S-s) \\
\hline Wilson 1984 & $\begin{array}{l}\text { Coexistence of Leptochelia dubia (S-s), Rhynchospio arenicola (S-s), Transenella tantilla (M-s), and } \\
\text { Paraphoxus spinosus (M-s) }\end{array}$ \\
\hline
\end{tabular}

pacifica, Upogebia pugettensis, and Callianassa californiensis (Brenchley 1982). The laboratory and field manipulations described above indicate that mobile animals can exclude sedentary organisms through burial and disruption of tubes and roots while sedentary species may bind the sediment or physically obstruct at least certain mobile burrowers.

However, most of these examples involve asymmetrical interactions in which large or active species exclude smaller forms or exclude organisms that individually have little effect on sediment characteristics. For example, thalassinid shrimps, such as Callianassa spp., reduce abundances of smaller tube-builders and bivalves (Table 1), but there is little indication that these small sedentary forms can affect burrowing shrimp distributions. In at least one case, C. californiensis distribution was shown to be limited primarily by predation and not by functional-group interactions (Posey 1986b). Sand dollars and burrowing worms excluding small spionids or tanaids and large tube- building worms and seagrasses excluding smaller, intermediate-sized burrowers provide other examples of asymmetrical responses (Table 1). A second type of interaction involves dense beds of an organism that collectively has very strong sedimentary effects, such as marshes or beds of thalassinid shrimps or seagrasses, negatively affecting individuals of large or intermediate-sized species of different mobility types. In such cases, a seagrass bed or marsh acts as a larger unit in modifying the sedimentary habitat. The modifications from such dense aggregations are consistently greater than those associated with the low densities of species they exclude (Stevens 1928, Warme 1967, Woodin 1981, Brenchley 1982).

In contrast, studies dealing primarily with small organisms or species of similar sizes have shown little or no mobility effects. A mobile bivalve coexisted with tube-builders in a dense assemblage, apparently due to insufficient sediment modification by the species present (Wilson 1984). Similarly, the burrowing polychaete 
Abarenicola pacifica excluded the small spionid polychaete Pygospio elegans but not the larger spionid Pseudopolydora kempi (Wilson 1981). The tube-dwelling amphipod Microdeutopus gryllotalpa (1 to $4 \mathrm{~mm}$ length) emigrated in the presence of a larger, mobile mud snail, Ilyanassa obsoleta (20 to $30 \mathrm{~mm}$ length) but not when exposed to a smaller deposit-feeding snail, Hydrobia totteni (2 to $4 \mathrm{~mm}$ length) (DeWitt \& Levinton 1985). The tube-building polychaete Clymenella torquata enhanced growth of the mobile bivalve Gemma gemma by increasing nutrients in the overlying water and decreasing organics at the sediment/ water interface (Weinberg \& Whitlatch 1983). The sedentary spionid polychaete Polydora ligni inhibited G. gemma, but the mechanism involved predation on juvenile clams and not interactions dependent on mobility types (Weinberg 1984).

Examination of seagrass communities also provides similar results. Densities of both small mobile and small sedentary species may increase in these beds, even when these species occur in high densities in adjacent areas (Homziak et al. 1982, Posey unpubl.). Neither group appears to cause a decline in numbers of the other. Seagrasses may have little negative effect on small mobile animals because the spacing between rhizomes is too large to bind sediments on the scale of these small infauna (Thayer 1983) or secondary effects, such as reduced predation or increased settlement, may become important. A combination of the scale of sediment binding and reduction of predation may also explain an increase of a variety of small infauna, including small mobile forms, within beds of a large, tube-building worm (Woodin 1981; although reduced predation within these worm beds was apparently due to inhibition of foraging by a mobile predator). The potential that sediment-binding effects, such as might be associated with seagrasses or dense beds of tube builders, may inhibit only a narrow size range of burrowers (or burrowers of restricted activity) has been largely overlooked. Yet it is possible that mobile animals may be large enough (or have a sufficiently high intensity of bioturbation) to disrupt roots or tubes while other species may be small enough to easily burrow between the same tube or root networks. Only mobile burrowers intermediate in relative size or sediment effects may be inhibited by the presence of such structures.

\section{CONCLUSIONS}

A review of the information on mobility interactions in soft sediments indicates that a mobility-mode functional group approach does provide a good framework for predicting the effects of dense aggregations of many larger species that produce significant sediment modifications. Larger animals that disrupt the sediment through burrowing or feeding activities can reduce numbers of smaller sedentary species while dense beds of species that bind sediments, such as seagrasses, marshes, or tube builders, may inhibit some burrowers. However, care should be taken in applying mobility interactions to explain other distributional relations. In particular, size effects and the magnitude of effects on the sedimentary environment should be considered. Few examples exist where smaller animals, no matter how dense, exclude larger active species.

However, a mobility-mode hypothesis may provide only part of the explanation for sediment-mediated interactions among organisms. Most of the available information involves species that directly affect depositional or erosion regimes through burrowing and feeding activities or through sediment binding - the type of effects that are the primary focus of a mobility-mode hypothesis. But, organisms that produce tubes or mounds projecting above the sediment surface can indirectly change resuspension rates by influencing local hydrodynamic processes (Woodin 1983). Such indirect effects are not considered within a mobilitymode approach to functional interactions though they may represent an important mechanism for sedimentmediated interactions. Functional interactions independent of mobility also may be important for dense assemblages in certain habitats. For example, the effects of resuspended matter on suspension feeders are expected to be greatest in subtidal or muddy areas (Rhoads \& Young 1970, Thayer 1983), with Callianassa spp. having been proposed to affect suspension feeders through trophic group amensalism in subtidal environments (Aller \& Dodge 1974, Murphy 1985).

Within the constraints described above, mobility interactions may provide an important framework for understanding certain patterns of distribution in softsubstrate communities. Although a variety of physical processes, settlement patterns (Butman 1986), or direct biological interactions (e.g. Peterson 1979) may dominate in determining community composition, functional group interactions, such as the mobility interactions discussed here, may become important in those specific instances involving dense species assemblages containing large or active organisms. Such a functional-group approach has an advantage of being less dependent upon taxonomy than approaches focused on individual species, an important consideration given the current uncertainty surrounding the taxonomic status of some common soft-substrate fauna (Anger 1984, Grassle \& Grassle 1976). The predictive power of a mobility-mode hypothesis, albeit under restricted conditions, indicates that indirect interactions can regulate benthic communities. However, the situations when many of these guild or functional-group interac- 
tions may predominate are poorly understood. Determining these conditions is essential to understanding their importance in controlling the composition of softsubstrate communities.

Acknowledgements. This review benefited from discussions with several people, especially Dr Peter Frank, Dr James Carlton, and Dr Eugene Gallagher, as well as from comments by 2 anonymous reviewers

\section{LITERATURE CITED}

Aller, R. C., Dodge, R. E. (1974). Animal-sediment relations in a tropical lagoon, Discovery Bay, Jamaica. J. mar. Res. 32: 209-232

Anger, V. (1984). Reproduction in Pygospio elegans (Spionidae) in relation to its geographical origin and to environmental conditions: a preliminary report. In: Fischer, A., Pfannenstiel, H. D. (ed.) Polychaete reproduction. Gustav Fischer Verlag, Stuttgart, p. 45-52

Bird, E. W. (1982). Population dynamics of the Thalassinidae shrimps and their community effects through sediment modification. Ph. D. dissertation, Univ. of Maryland, College Park

Brenchley, G. A. (1978). On the regulation of marine infaunal assemblages at the morphological level: a study of the interactions between sediment stabilizers, destabilizers, and their sedimentary environment. Ph. D. dissertation, The Johns Hopkins Univ., Baltimore

Brenchley, G. A. (1981). Disturbance and community structure: an experimental study of bioturbation in marine softbottom environments. J. mar. Res. 39: 767-790

Brenchley, G. A. (1982). Mechanisms of spatial competition in marine soft-bottom communities. J. exp. mar. Biol. Ecol. 60: $17-33$

Butman, C. A. (1986). Larval settlement of soft-sediment invertebrates: some predictions based on an analysis of near-bottom velocity profiles. In: Nilhoul, J. C. J. (ed.) Marine interface ecohydrodynamics. Elsevier, Oxford, p. $487-513$

DeWitt, T. H., Levinton, J. S. (1985). Disturbance, emigration, and refugia: how the mud snail, Ilyanassa obsoleta (Say), affects the habitat distribution of an epifaunal amphipod, Microdeutopus gryllotalpa (Costa). J. exp. mar. Biol. Ecol. 92: $97-113$

Dorsey, J. H., Synnot, R. N. (1980). Marine soft-sediment benthic community offshore from the Black Rock sewage outfall, Connewarre, Victoria, Australia. Aust. J. mar. Freshwat. Res. 31: 155-162

Grant, D. C. (1965). Specific diversity in the fauna of an intertidal sand community. Ph. D. dissertation, Yale Univ., New Haven

Grassle, J. P., Grassle, J. F. (1976). Sibling species in the marine pollution indicator Capitella (Polychaeta). Science 192: $567-569$

Highsmith, R. C. (1982). Induced settlement and metamorphosis of sand dollar (Dendraster excentricus) larvae in predator-free sites: adult sand dollar beds. Ecology 63: 329-337

Homziak, J., Fonseca, M. S., Kenworthy, W. J. (1982). Macrobenthic community structure in a transplanted eelgrass (Zostera manina) meadow. Mar. Ecol. Prog. Ser. 9: 211-221

Josefson, A. B. (1985). Distribution of diversity and functional groups of marine benthic infauna in the Skagerrak (Eastern North Sea) - can larval availability affect diversity? Sarsia 70: 229-249

Murphy, R. C. (1985). Factors affecting the distribution of the introduced bivalve, Mercenaria mercenaria, in a California lagoon - the importance of bioturbation. J. mar Res. 43: 673-692

Peterson, C. H. (1977). Competitive organization of the softbottom macrobenthic communities of southern California lagoons. Mar. Biol, 43: 343--359

Peterson, C. H. (1979). Predation, competitive exclusion and diversity in the soft-sediment benthic communities of estuaries and lagoons. In: Livingston, R. J. (ed.) Ecological processes in coastal and marine systems. Plenum Press, New York, p. 233-262

Posey, M. H. (1985). The effects upon the macrofaunal community of a dominant burrowing deposit feeder, Callianassa californiensis, and the role of predation in determining its intertidal distribution. Ph. D. dissertation, Univ. of Oregon, Eugene

Posey, M. H. (1986a). Changes in a benthic community associated with dense beds of a burrowing deposit feeder, Callianassa californiensis. Mar. Ecol. Prog. Ser. 31: 15-22

Posey, M. H. (1986b). Predation on a burrowing shrimp: distribution and community consequences. J. exp. mar. Biol. Ecol. 103: 143-161

Rhoads, D. C., Young, D. K. (1970). The influence of depositfeeding organisms on sediment stability and community trophic structure. J. mar. Res. 28: 150-178

Ronan, T. E. (1975). Structural and paleo-ecological aspects of a modern soft-sediment community: an experimental study. Ph. D. dissertation, Univ. of California, Davis

Stevens, B. A. (1928). Callianassidae from the west coast of North America. Publs Puget Sound mar. biol. Stn 6: 315-369

Suchanek, T H. (1983). Control of seagrass communities and sediment distribution by Callianassa (Crustacea, Thalassinidae) bioturbation. J. mar. Res. 41: 281-298

Thayer, C. W. (1983). Sediment-mediated biological disturbance and evolution of marine benthos. In: Tevesz, M. J. S., McCall, P. L. (ed.) Benthic communities. Plenum Press, New York, p. 479-625

Warme, J. E. (1967). Graded bedding in the recent sediments of Mugu Lagoon, California. J. sedim. Petrol. 37: 540-547

Weinberg, J. R. (1984). Interactions between functional groups in soft-substrata: do species differences matter? J. exp. mar. Biol. Ecol. 80: 11-28

Weinberg, J. R., Whitlatch, R. B. (1983). Enhanced growth of a filter-feeding bivalve by a deposit-feeding polychaete by means of nutrient regeneration. J. mar. Res. 41: 557-569

Wildish, D. J. (1986). Geographical distribution of macrofauna on sublittoral sediments of continental shelves: a modified trophic ratio concept. In: Gibbs, P. E. (ed.) Proceedings of the 19th European Marine Biology Symposium. Cambridge Univ. Press, Cambridge, p. 335-346

Wilson, W. H. (1981). Sediment-mediated interactions in a densely populated infaunal assemblage: the effects of the polychaete Abarenicola pacifica. J. mar. Res. 39: 735-748

Wilson, W. H. (1984). An experimental analysis of spatial competition in a dense infaunal community: the importance of relative effects. Estuar. coast. Shelf Sci. 18: $673-684$

Wiltse, W. I. (1980). Effects of Polinices duplicatus (Gastropoda: Naticidae) on infaunal community structure at Barnstable Harbor, Massachusetts, USA. Mar. Biol. 56: 301-310

Woodin, S. A. (1976). Adult-larval interactions in dense 
infaunal assemblages: patterns of abundance. J. mar. Res. 34: $25-41$

Woodin, S. A. (1981). Disturbance and community structure in a shallow water sand flat. Ecology 62: 1052-1066

Woodin, S. A. (1983). Biotic interactions in recent marine sedimentary environments. In: Tevesz, M. J. S., McCall, P. L. (ed.) Benthic communities. Plenum Press, New York, p. 3-38

Woodin, S. A., Jackson, J. B. C. (1979). Interphyletic competition among marine benthos. Am. Zool. 19: 1029-1043

This review was submitted to the editor; it was accepted for printing on April 30, 1987 